\title{
Erratum to: The progressive fragmentation of the KIT/PDGFRA wild-type (WT) gastrointestinal stromal tumors (GIST)
}

\author{
Margherita Nannini ${ }^{1 *}$, Milena Urbini ${ }^{2}$, Annalisa Astolf ${ }^{2}$, Guido Biasco ${ }^{1,2}$ and Maria A. Pantaleo ${ }^{1,2}$
}

\section{Erratum to: J Transl Med (2017) 15:113 DOI 10.1186/s12967-017-1212-x}

In the original version of this article [1], published on 23 May 2017, the name of author 'Maria A. Pantaleo' was wrongly displayed.

Originally the author name has been published as:

- Mara A. Pantaleo

The correct author name is:

- Maria A. Pantaleo

The original publication of this article has been corrected.

\section{Author details}

${ }^{1}$ Department of Specialized, Experimental and Diagnostic Medicine, Sant'Orsola-Malpighi Hospital, University of Bologna, Via Massarenti 9, 40138 Bologna, Italy. ${ }^{2 ~ " G i o r g i o ~ P r o d i " ~ C a n c e r ~ R e s e a r c h ~ C e n t e r, ~ U n i v e r s i t y ~}$ of Bologna, Bologna, Italy.
The online version of the original article can be found under doi:10.1186/s12967-017-1212-x.

\section{Publisher's Note}

Springer Nature remains neutral with regard to jurisdictional claims in published maps and institutional affiliations.

Published online: 02 June 2017

\section{Reference}

1. Nannini, et al. The progressive fragmentation of the KIT/PDGFRA wild-type (WT) gastrointestinal stromal tumors (GIST). J Transl Med. 2017;15:113. doi:10.1186/s12967-017-1212-x.

\footnotetext{
*Correspondence: margherita.nannini@unibo.it

1 Department of Specialized, Experimental and Diagnostic Medicine,

Sant'Orsola-Malpighi Hospital, University of Bologna, Via Massarenti 9,

40138 Bologna, Italy

Full list of author information is available at the end of the article
} provided you give appropriate credit to the original author(s) and the source, provide a link to the Creative Commons license, and indicate if changes were made. The Creative Commons Public Domain Dedication waiver (http://creativecommons.org/ publicdomain/zero/1.0/) applies to the data made available in this article, unless otherwise stated. 